\title{
THE EFFECT OF THE BULK SALES ARTICLE ON EXISTING COMMERCIAL PRACTICES
}

\author{
Frank W. MrLLER*
}

The phrase "commercial practices" as used in the title of this article requires definition. I suggest two possible meanings. First, commercial practices may mean the aggregate of actions taken by parties to business transactions. In particular it may involve a determination of whether goods are usually sold to a retailer by a wholesaler or by a manufacturer in a particular industry; whether wholesalers in the industry sell on open account or for cash, and if the former, what the usual credit terms are; whether the wholesaler usually seeks and obtains security if he sells on credit; whether a particular class of lender is used if the wholesaler or manufacturer sells for cash; whether, if the transaction is a secured one, the chattel mortgage, conditional sale, consignment, or other security device is customarily employed. Obviously it may include a multitude of other questions. The Bulk Sales Article will have little effect on "commercial practices" so defined, at least when considered apart from the rest of the Code.

Second, commercial practices may mean the steps taken as a matter of practice when a possible or certain bulk sales situation arises. It is in this sense that the phrase is used in this article.

In order to acquire some information as to what the present practices are, over and above what may be gleaned from an investigation of existing statutes and the cases decided under them, a questionnaire containing the following seven questions was prepared:

I. Please describe in detail just what steps are followed in complying with the bulk sales law of your state in the ordinary cases.

2. To what extent are escrow arrangements used?

3. Do you ever require a bond from the seller as a substitute for compliance?

4. Are there a large number of transactions in which the law is ignored because of the undoubted solvency and honesty of the seller?

5. In your opinion, is there any actual fraud in any substantial percentage of sales in which the statute is not complied with?

6. What, in your opinion, are the principal reasons for the decrease in bulk sales litigation during the past ten years?

7. What, in your opinion, will be the principal effects on commercial practices in your area of the Bulk Sales Article of the Uniform Commercial Code, if it should be adopted?

The questionnaire was sent to the Managers of Credit Men's Associations in twenty-five major cities. Replies have been received from thirteen managers, and

* B.A. 1946, LL.B. 1948, University of Wisconsin. Member of the Wisconsin bar. Assistant Professor of Law, Washington University, since I948. Employed by the American Law Institute as a research assistant for the Uniform Commercial Code, r948. 
those replies serve as the basis for my conclusions as to what the "commercial practice" is in the areas covered.

Before embarking on that phase, however, it is necessary to describe bulk sales statutes generally and to examine the provisions of the Bulk Sales Article of the Uniform Commercial Code.

The first bulk sales statute was enacted in 1896 in Louisiana. It came as the result of dissatisfaction with what was considered a defect in the law of fraudulent conveyances, i.e., the situation where the purchaser of a stock of goods could not be proved to have had any fraudulent intent even though there was clearly fraud on the part of the seller. In some jurisdictions ${ }^{2}$ such a sale was treated as a "Badge of Fraud," but even this procedural aid was denied creditors in other jurisdictions. ${ }^{3}$ The purchaser had goods for which he had paid, and the seller went to parts unknown with the purchase money, leaving his creditors unpaid. In order to prevent such occurrences, statutes have been enacted in every state and the District of Columbia which provide either that a sale of the proscribed type may be avoided by creditors unless the act is complied with, or that such a sale not in compliance with the act results in a prima facie case of fraud. Although many of the statutes were modeled on that of New York, and others on that of Pennsylvania, there are significant variations even within these classes. ${ }^{4}$ Some features of each are incorporated in the proposed statute under consideration and will be discussed in connection therewith.

The provisions of the Uniform Commercial Code relating to Bulk Transfers comprise Article to of that code, and are contained in some eleven sections. The first section merely states the name of the article. The second section is as follows:"

(I) A "bulk transfer" is any transfer in bulk and not in the ordinary course of the transferor's business of a major part of the materials, supplies, merchandise or other inventory (Section 9-rog) of an enterprise subject to this Article, or of so much thereof that what remains, together with the transferor's other assets exclusive of the consideration received for the transfer, is inadequate capital for the regular conduct of his business.

(2) "Transfer" includes the voluntary creation of a lien or other security interest in such property.

${ }^{2}$ La. Laws 1896 , No. 94 .

${ }^{2}$ See, e.g., Pennell v. Robinson, I64 N. C. 257,80 S. E. 417 (1913); I Garrard Glenn, Fraudulent Conveyances and Preferences $\$ 309$ (Rev. ed. 1940) states that this is the common law rule.

${ }^{2}$ Hart v. Roney, 93 Md. 432, 49 Atl. 66I (Ig0I). And see Note, 72 CENT. L. J. 300 (I9II).

- There are said to be four principal forms of bulk sales statutes, the Pennsylvania form, the New York form, the Connecticut form, and the Montana form. Montgomery, Laws and Decistons Applyino to Sales in Bulk (2d ed. I926); See PA. Stat. ANN. tit. 69, \$521-529 (Purdon, Perm. ed.); N. Y. Pers. Prop. Law \$44; III Conn. Gen. Stat. \$\$6705-7 (1949); Mont. Laws 1907, c. I45 as amended by Mont. Laws 1915, c. 128. The Montana statute was amended by Mont. Laws 1931, c. 106, to conform to the Pennsylvania form. See Monr. Code $\$ \$ 8607-86$ I I (1935).

${ }^{5}$ Unless otherwise indicated the draft of the Bulk Transfer Article referred to is the Proposed Final Draft of Spring 1950 as corrected by a letter of November 16, I950 from the Reporter for Article Io, Professor Charles Bunn, to the Director of the American Law Institute. No policy questions are raised by the changes. 
(3) A transfer of a substantial part of the equipment (Section 9-rog) of such an enterprise is a bulk transfer if it is made in connection with a transfer of inventory, but not otherwise.

(4) The enterprises subject to this Article are all those whose principal business is the sale of merchandise from stock including those who manufacture what they sell.

(5) Except as limited by the following section all bulk transfers of goods located within this state are subject to this Article.

Certain key terms should be discussed in the light of their meaning under existing statutes. The first of these is "in bulk." Considered apart from its relationship to the phrase "and not in the ordinary course of the transferor's business of a major part of . ..", "in bulk" would seem to be descriptive of a sale ". . . where separating, counting, measuring, weighing or dividing in parcels, packages or barrels does not

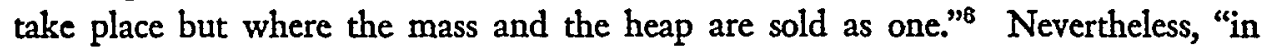
bulk" has been rather a term used to determine whether successive transfers of parts of a business fall within this type of statute. It has also served as a sort of quantitative test in situations where the statute does not contain a relative quantitative minimum. ${ }^{8}$

The next key term is "not in the ordinary course of the transferor's business ..." This phrase suggests a qualitative determination, ${ }^{9}$ and means simply "is this the sort of transaction in which this merchant normally engages?" It should be noted that the reference is to "the transferor's business" (italics added) and not to businesses of the same general type. Thus custom in the industry, apart from a showing that this seller operated in the same way, would appear to be immaterial. ${ }^{10}$

"Major part" seems to be the next key phrase. This term means simply more than one-half of the total stock. The act is prima facie applicable ${ }^{11}$ when that pro portion is sold. It should be noted, however, that there is an alternative situation: "or of so much thereof that what remains, together with the transferor's other assets exclusive of the consideration received for the transfer, is inadequate capital for the regular conduct of his business." This is an entirely new idea, in so far as this writer knows. It is found in none of the existing statutes. It presents a new problem of a somewhat different nature to the attorney who must decide whether his client must comply with the statute. The criterion is not, strictly speaking, that of solvency or insolvency, but it is a related idea. The determination is, of course, a factual one, and it may not be simple. It appears that the effect will be to force compliance in close cases in order that the purchaser will be fully protected. That seems desirable.

\footnotetext{
- Feldstein v. Fusco, 205 App. Div. 806, 809, 201 N. Y. Supp. 4, 6 (3d Dep't I923).

'Stcin v. Doran, 266 App. Div. 755, 4I N. Y. S. 2d 28I (2d Dep't x943); Conquest v. Atkins, 123 Me. 327, 122 Atl. 858 (1923).

Krueger v. Hammond, I23 Kan. 319, 255 Pac. 30 (1927). Kans. Gen. Stat. AnN. \$58-ror (I935) provides in part: "The sale or disposal of any part or the whole. . .."

- Billig and Branch, The Problem of Transfers Under Bulk Sales Laws: A Study of Absolute Transfers and Liquidating Trusts, 35 Mick. L. REv. 732 (1937).

${ }^{10}$ Cohen v. Calhoun, 168 Miss. 34 , 150 So. 198 (1933).

${ }^{11}$ The term "prima facie applicable" is used because of the exceptions stated in Section ro-ro3, and particularly Subsection ro-ro3(6).
} 
When what is sold is "equipment," rather than "inventory," a different test is applied. That test is "substantial part."12 Again a factual determination must be made in each case, it appearing that "substantial part" may be less than a "major part," one of the tests used in determining whether a sale of inventory is included. It should be noted that a sale of equipment alone is not interdicted by the statute.

Realism requires, however, that the above phrases be considered collectively rather than individually. There seem to be four separate factual determinations called for, but in reality that is not true. They are (I) was the sale "in bulk," (2) was it "not in the ordinary course of the transferor's business," (3) was it either (a) of a "major part" of the materials, etc. of the enterprise or (b) "of so much thereof that what remains, together with the transferor's other assets exclusiye of the consideration received for the transfer, is inadequate capital for the regular conduct of his business," and (4), if a transfer of equipment as well as inventory, was it of a "substantial part of the equipment?" .

- "In bulk," as defined by the New York Supreme Court, seems to be a rather unwise phrase to include in the statute. Surely it is not material that the stock of goods is either itemized or not itemized, that a per unit price is or is not set on each.item. Something else must have been intended. As suggested above, "in bulk" has served as a relative quantitative minimum in states having statutes which prohibit the sale of "any part." While the section we are considering contains the limitation "major part," there is no specific quantitative minimum set in the alternative situation. In the determination of whether enough is left to carry on the business in the usual way, the quantity sold may vary from little to much. Certain businesses are always that close to the "brink." I suggest that "in bulk" serves as a relative quantitative minimum when the problem is the determination of whether enough has been sold so that what is left is not enough to conduct the business in the regular manner.

"In bulk" and "not in the ordinary course of the transferor's business" have been șo interwoven in judicial decisions that it is nearly impossible to determine where one ends and the other begins. ${ }^{13}$ It is believed that the use of "in bulk" in this section is justified on two grounds; (I) the reason stated above, i.e., to serve as a relative quantitative minimum when the issue is whether enough has been sold so that what is left is not enough to run the enterprise in the regular way, and (2) because "bulk sales" is now a generic term in common usage to describe this type of transaction.

Wathin the same section is included a description of the types of businesses

\footnotetext{
12 The statutes of five states now contain similar terminology, but the reference is not cxclusively to "equipment." It is generally applicable in those statutes to the merchandise as well. Sec CaL. CIv. Code $\$ 3440$ (Deering, I949) (substantial part); Kr. Rev. Stat. \$377.010 (I946) (large part); N. J. Rev. Stit. tit. 46 , c. 29, $\$$ I (1937) (large part); N. C. GeN. STAт. \$39-23 (r943) as amended by N. C. Laws, I945, c. 635 (large part); PA. Stat. ANN. tit. 69, $\$ 525$ (Purdon, Perm. ed.). The Oregon statute refers to "all or substantially all of the fixtures." ORE. Comp. LAws ANN. C. 4, art. 2 (1940) as amended by Ore. Laws r949, c. 435 .

${ }^{13}$ Billig and Branch, supra note 9.
} 
covered, a description of the type of goods covered, a description of the kind of transfers covered, and a statement that all bulk transfers of goods within the state are subject to the Article. Subsection ro-ror(4) contains, in one sense, a somewhat broader description of businesses covered than is usually found in existing statutes, while in another sense it is narrower than that found in some others. Thus it would include retailers, wholesalers, and manufacturers. Usually manufacturers, ${ }^{14}$ and occasionally wholesalers, ${ }^{15}$ are excluded from the operation of bulk sales statutes. Conversely it excludes all service establishments, while some of the existing statutes cover service establishments. ${ }^{16}$ The Reporter recognizes that some bulk sales risks inhere in the excluded businesses, but he wisely points out that ". . . unsecured credit is not commonly extended in the faith either of a stock of merchandise or of equipment . .." in the case of businesses which sell services rather than goods. ${ }^{17}$ In terms of commercial practice this means simply that there will be a change one way or the other in most jurisdictions as to which businesses are included in the Act.

Section 9-I09 of the Code defines "inventory" as follows:

Goods are

(5) "inventory" if they are held or are being prepared for sale or furnished under a contract of service or if they are raw materials, work in process or materials used or consumed in a business. Inventory does not include farm products or equipment;

and defines "equipment" as follows:

Goods are

(3) "equipment" if used by a debtor in business (including farming or a profession) or by a debtor who is a non-profit organization or a governmental subdivision or agency or if they are not included in the definitions of inventory, farm products or consumer goods. Equipment does not include goods which at the time a security interest attaches are being held or prepared for sale in the ordinary course of the debtor's business ...

${ }^{14}$ See e.g., Frederick v. Dettary Engineering Co., 318 Mich. 252, 28 N. W. $2 d 94$ (1947). Cases are collected in Notes, 168 A. L. R. 735 and 762 (1947).

${ }^{15}$ Connecticut Steam Brown Stone Co. v. Lewis, 86 Conn. 386, 85 Atl. 534 (I912). The Connecticut statute at that time applied only to one ". . who makes it his business to buy commodities and sell the same in small quantities for the purpose of making a profit...." Conn. Laws r903, c. 72. The statute has since been amended and is apparently broad enough to include wholesalers. III ConN. Gen. Stat. \$\$6705-7 (1949).

${ }^{10} \mathrm{Cal}$. Civ. Code $\$ 3440$ (Deering, 1949) ". . of the fixtures or store equipment of a baker, cafe, or restaurant owner, garage owner, machinist, cleaner and dyer. ..." IDAHO CODE ANN. tit. 64, \$7OI (I949) ". . or any portion of the property ... of a hotel, restaurant, barber shop or any place of business wherein the furniture, fixtures, or equipment are used in carrying on said business. ..." 3 NEB. REv. STAT. c. 36, $\$ 501$ (Supp. I949) “. . . by any person . . . engaged in a business in which no stock of merchandise is maintained. . . " Ore. Laws 1949 , c. 435 “. . . any commercial business or establishment, including restaurants and other food dispensing establishments. . ." 2 UTAH Code ANN. tit. 33, c. 2, §I (I943) “. . . property . . . of a hotel, restaurant, barber shop or other business. . . " 7 Wash. Rev. Stat. ANn. $\$ 5832$ (Remington 1932) as amended by Wash.'Laws r939, c. r22 and Wash. Laws 1943, c. 98 ". . . or any restaurant, cafe, beer parlor, tavern, hotel, club or gasoline service station. ..."

${ }^{17}$ Comment to $\$ 7-701$ of the May I949 Draft of the Code. $\$ 7-701$ is now, in substance, $\$ 10-102$ of the Code. 
The phraseology of the section seems designed to be an integral part of the statement of businesses covered. Thus it would seem to cover all chattels owned by a business except those expressly excepted by the above subsections. Most important among the different possible kinds of chattels within the "equipment" class would be what are presently described in bulk sales statutes as "fixtures," although obviously "equipment" is a broader word than "fixtures." Roughly speaking, it includes all tangible chattels, both real and personal, which are used in any of the included businesses except those specifically excepted. The definition of inventory is broad enough to include manufacturing businesses. The language of Section ro-102 clearly excludes from the statute transfers of intangibles such as accounts receivable and good-will.

Subsection 10-ro2(2) states:

(2) "Transfer" includes the voluntary creation of a lien or other security interest in such property.

The language precludes a holding, common under some statutes, that whether a chattel mortgage is interdicted by the statute depends on whether the state is a "lientheory" or "title-theory" state. ${ }^{18}$

Section I0-ro3 enumerates those transfers which are excepted from the Article. The first exception is stated thus:

(x) Those made for the sole purpose of giving security for the repayment of new value extended to the transferor (Section 9-rrr). But if a bulk transfer also secures existing debts it is subject to this Article as to them;

Whether chattel mortgages and pledges are transfers within the meaning of that term as found in existing bulk sales acts is a controversial question. ${ }^{19}$ Some of the existing statutes contain provisions which bring bulk mortgages within them. ${ }^{20}$ In other jurisdictions separate statutes relating to bulk mortgages may be found. ${ }^{21}$ As indicated above, where there is no express statutory provision, the courts have disagreed, and the turning point has usually been whether title passed to the mortgagee. What is important is that this statute clearly provides an answer, and a very sensible one. Transfers made to give security for new value are excluded. The reason is that those transfers are completely covered in Article 9 of the Code. It would seem that any security transfer for new value, except one of the purchase-money chattel mort-

${ }^{18}$ See, e.g., Linn County Bank v. Davis, I03 Kans. 672, 175 Pac. 972 (19r8).

${ }^{10}$ See I Garrard GlenN, Fraudulent Conveyances and Preferences (Rev. ed. 1940) \$310; Note: 20 Iowa L. Rev. 815 (1935); 33 Micr. L. Rev. 456 (1934); 5 I NAT. CoRp. Rep. 353 (1915); Legis. 44 Harv. L. Rev. 638 (1931); Montgomery, The Bulk Sales Law As It Was Intended to Be and As lt ls, 25 Cr. Montrily 8 (May, 1923).

${ }^{20} 6$ ARx. STAT. ANs. tit. 68, $\$ 1501-1504$ (1947) (Mortgages on fixtures only and where goods have been stored or deposited in compliance with the Warehouse Receipts Act are excluded); Cat. Civ. Codz \$3440 (Deering, 1949) (covers mortgages on fixtures only and specifically excludes mortgages made for the benefit of ereditors generally; also excludes Warehouse Receipts situation); LA. GEN. STAT. ANN. tit. 58, c. 3, 55 (Dart, 1939) (includes pledges and mortgages without qualification.)

${ }^{2 x}$ Mich. Comp. Laws \$\$442.5x-442.53 (1948); N. Y. LieN Law \$230a; Okra. Stat. tit. 46, \$gr (1949 Supp.). 
gage variety, would contain the same danger of prejudicing creditors that a sale would, but the decision on that issue was made elsewhere in the Code. ${ }^{22}$

The second exception is stated thus:

(2) General assignments for the benefit of all the creditors of the transferor, and subsequent transfers by the assigneee thereunder

Three things should be noted: (I) the assignment must be for the benefit of all creditors, (2) nothing prohibits the assignor's requiring a release of the entire debt as a condition of participation, and (3) subsequent transfers by the assignee are excluded. The explanation is that a general assignment does not prejudice creditors, it benefits them. This provision may encourage the use of general assignments in those jurisdictions where they are not now excluded from the bulk sales statutes.

Subsection (3) states that "Sales in foreclosure of a lien or other security interest" are excluded. There have been some holdings that even though the transfer of a security interest is not within the statute, the foreclosure of the interest is within it. ${ }^{23}$ That problem, with its unfortunate solution, is eliminated.

Subsection (4) provides that "sales by executors, administrators, receivers, trustees in bankruptcy, or any public officer under judicial processs" are excluded. A similar provision is found in almost all of the existing statutes.

Subsection (5) is stated as follows:

Sales made in the course of proceedings for the dissolution of a corporation and of which the creditors of the corporation receive advance notice substantially equivalent to that provided in this Article;

This provision is new but it is self-explanatory and seems eminently sensible.

The next subsection is one of the key parts of the Article. It excepts:

(6) Transfers to a person maintaining a known place of business in this state who becomes bound to pay the debts of the transferor in full and gives public notice of that fact, and who is solvent after becoming so bound;

This section is unlike anything found in any of the existing statutes. It represents a recognition of the fact that this Article imposes a substantial amount of red tape. The idea is that the red tape should be eliminated as much as possible. Thus the Comment to the Section states in part: "If the buyer is willing to assume personal liability for those debts and is himself solvent after such assumption, there is no reason to subject the transaction to the delay and red tape which this Part imposes."24 This provision will have a great impact on commercial practices as I have defined them. What we have is a real alternative to compliance with the statute in a situation where it seems that such an alternative should be present. It will mean that where there is a need for speed, as is often the case, the buyer may choose to assume liability.

\footnotetext{
${ }^{22}$ See Code $\$ 9-107$, particularly Subsection (c) thereof.

${ }^{23}$ Vaughan v. Tyler, 206 Mo. App. I, 226 S. W. 1034 (1920). The case, however, was overruled in Farmers' Cooperative Co. v. Bank of Leeton, 3ig Mo. 548, 4 S. W. $2 d$ ro68 (I928).

26 Comment to $\$ 7-703$ of the May 1949 Draft, which is in substance the present Section 10-103.
} 
He will do this, obviously, only where he can be certain that he knows all of the seller's creditors, and where the seller's debts do not exceed the agreed price for the goods. He may also require a bond of the seller if he deems it necessary. The creditors are in no position to complain. They have a direct action against a solvent person who can be located easily. They are in a much better position than they would otherwise be, and can probably collect with a minimum of expense and trouble.

Subsection (7) is another very important part of this Article. It excepts:

(7) A transfer to a new business enterprise oganized to take over and continue the business, if the new enterprise assumes the debts of the transferor and he receives nothing from the transaction except an interest in the new enterprise junior to the claims of creditors;

This too embodies a new idea. There has been a wide variance on the point in the cases ${ }^{25}$ only one of the existing statutes expressly covers the situation. ${ }^{20}$ The Reporter points out that "... in all the transactions to which the subsection applies (a) both the original debtor and the new enterprise are personally bound to pay the debts, (b) the property subject to the debts before the transfer is still subject to them, and (c) the original debtor has taken nothing out of the transaction except an interest (shares in a corporation or an interest in a firm) which is junior to the debts." Again, this seems to be a sensible exception and of great value in eliminating the red tape referred to above.

Subsection (8) simply excepts property exempt from execution, a clearly proper rule since the sale of exempt property could in no way prejudice creditors.

Sections I0-I04, I0-I05, and I0-I06 provide that a bulk transfer shall be ineffective as against any creditor of the transferor unless certain things are done. The phrase chosen to describe the effect of non-compliance is not found in any of the existing statutes. They are rather framed in fraudulent conveyance terms; thus, void, ${ }^{27}$ fraudulent and void, ${ }^{28}$ presumed to be fraudulent and void, ${ }^{29}$ conclusively presumed

${ }^{28}$ Cases are collected in Note, 96 A. L. R. 1213 (1935).

${ }^{20}$ LA. Gen. Stat. ANN. tit. 58, c. 3, \$5 (Dart, 1939).

${ }^{27} 4$ ARIz. Code ANN. \$58-301 (I939); 6 ARK. Stat. ANN. tit. 68, \$1501 (1947); Colo. StAT. ANN. c. 27, §1 (1935); III Conn. Gen. Stat. \$6705 (1949); 7 Ind. Stat. Ann. \$33-201 (Burns, 1933); II Iowa Code \$555.x (1950); Kans. Gen. Stat. Ann. \$58-ror (1935); La. Gen. Stat. Ann. tit. 58, c. 3, §I (Dart, 1939); II ME. Rev. Stat. c. Io6, 66 (1944); 3 Mich. Comp. Laws \$442.1 (1948); Neग. Rev. Stat. \$36-501 (Supp. I949); 4 N. M. Stat. ANn. \$53-I00I (I94I); N. Y. Pers. Prop. Law \$44;

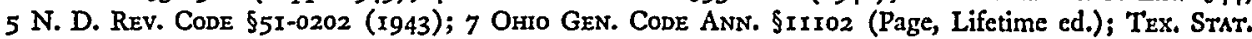
art. 4001 (Vernon, 1948); 8 VA. CODE $\$ 55-83$ (1950).

${ }^{28}$ IDAHo CODE, tit. 64, $\$ 702$ (I949); IlL. REv. STAT. c. r2I 1/2, $\$ 78$ (1945) as amended by Ill. Laws I947, p. 1516; Ky. Rev. Stat. \$377.050 (1946); MD. CODE ANN., art. 83, \$98 (Flack, I939); III Mass. Laws Ann., c. ro6, §x (Michie, 1946 Recomp.); Mo. Rev. Star. \$3517 (r939); 2 Mont. Rev. Code Ann. \$I8-202 (I947); 3 Nev. CoMp. Laws \$6817 (Hillyer, I929); II N. H. Rev. Laws, c. 262, \$43 (1942); PA. Stat. Anv. tit. 69, $\$ 523$ (Purdon, Perm. ed.); R. I. Gen. Laws tit. L, c. 483, §I (1938); 2 UTAh Code ANn., \$33-2-2 (1943); VT. Pub. Laws \$79r8 (1933); 7 Wash. Rev. Stat. ANn. \$5833 (Remington, I932) as amended by Wash. Laws I939, c. I22 and Wash. Laws I943, c. 98.

20 Ara. CODE, tit. 20, §10 (1940); Del. REv. Code, §3rIO (1935); II MinN. Stat., §513.18 (1945); I Miss. Code AnN., \$274 (1942); Okta. Stat. AnN., tit. 24, c. 3, \$7I (r94I); 5 Tenn. Code Ann. \$7283 (Williams, 1934). 
to be fraudulent and void, ${ }^{30}$ conclusively presumed to be fraudulent, ${ }^{31}$ presumed to be fraudulent, ${ }^{32}$ voidable, ${ }^{33}$ prima facie be presumed to be fraudulent and void, ${ }^{34}$ presumed to be fraudulent and therefore void, and shall be held to be prima facie void. $^{35}$ As might be expected, a variety of judicial opinion as to the meaning of such phrases has resulted. ${ }^{36}$ The courts have not held that any of the above phrases means "void" literally, i.e., of no effect even between the parties, but they have disagreed as to whether a rule of substantive law or a rule of evidence had been enacted. ${ }^{37}$ The question has been resolved into one of whether a non-complying purchaser can prevail when he demonstrates that he acted in good faith. Again, the significance of the Section under consideration is that that problem has been avoided. Clearly the transfer can be avoided by creditors in any case where there is noncompliance. This, of course, will have its greatest effect in those jurisdictions which presently hold that a sale not in compliance is only prima facie void.

The requirements for compliance are not all found in the same Section: 'The reason is that each requirement is not applicable to every type of transfer. Section I0-I04 provides that three things must be done in every type of bulk transfer subject to the Article except as otherwise provided in Section ro-ro8, relating to auction sales. Those three things are: (I) The transferee must require the transferor to furnish a list of his existing creditors. The list

... must be signed and sworn to or affirmed by the transferor or his agent. It must contain the names and business addresses of all creditors of the transferor, with the amounts when known, and also the names of all persons who are known to the transferor to assert claims against him even though such claims are disputed.

(2)A schedule of the property transferred sufficient to identify it must be prepared. (3) The list and schedule must be preserved by the transferee for six months: after the transfer and the transferee must permit inspection of either or both or copying therefrom at all reasonable hours by any creditor of the transferor, or alternatively, the transferee may file the list and schedule in a public office. "Responsibility for the completeness and accuracy of the list rests on the transferor, and the transfer is not rendered ineffective by errors or omissions therein unless the transferee is shown to have had knowledge."

The first and second of these requirements are found in nearly all of the existing statutes, the schedule of property being more often referred to as an inventory. In most statutes, there is a provision requiring that the cost price of each item be listed

\footnotetext{
${ }^{30} \mathrm{CAl}$. Crv. COdE, $\$ 3440$ (Deering, I949); Ore. Comp. Laws ANN. c. 4, art. 2 (I940) as amended by Ore. Laws, I949, C. 435; WIs. STAT. \$24I.I8 (I949); D. C. Code \$28-1702 (1940).

${ }^{31} \mathrm{GA}$. CODE, $\$ 28-205$ (I933).

${ }^{32}$ Fla. Stat. \$726.04 (I94I).

${ }^{33}$ N. J. Rev. Stat. tit. 46 , c. 29 , \$I (I937).

st 3 S. C. CODE $\$ 66 \mathrm{I}_{7}$ (1942).

${ }^{35} 3$ Wyo. Comp. Stat. ANn. \$4I-70I (I945).

${ }^{30}$ See Note, 75 A. L. R. 674 (I93I) for a collection of cases.

${ }^{37}$ Ibid.
} 
if possible. ${ }^{38}$ That requirement represents the epitome of the red tape referred to above. What is needed is sufficient definiteness that the property may be identified, and, of course, that is the provision of the Section under consideration.

The purpose of the third requirement is to aid in carrying out one of the purposes of bulk sales acts, i.e., to aid in carrying out the policies of the Uniform Fraudulent Conveyances Act and of the Bankruptcy Act. Thus the schedule and list are available so that creditors may know whether they can attack the transfer as a conveyance fraudulent in fact, either in bankruptcy proceedings or otherwise, even though the Bulk Transfer Act has been complied with. The requirement is thus a salutary one.

Subsection (3), quoted above, places responsibility for omissions from the list of creditors squarely where it belongs, on the only person who in fact has such knowledge that it is fair to place responsibility on him-the transferor. Lack of similar language in the present statutes has caused some difficulty, with at least one court holding that the responsibility rests with the transferee. ${ }^{39}$ While that decision is extremely unfortunate from the point of view of both fairness and commercial expediency, a still more important result is the fact that a good deal of money has been spent in litigating a matter when the inclusion of a simple provision like the one we are considering could have avoided that expenditure and waste.

Section I0-105 states additional requirements-those relating to notice to creditors of the transferor-as follows:

In addition to the requirements of the preceding Section:

(I) A bulk transfer subject to this Article which is made to secure an existing debt or debts is ineffective against any creditor of the transferor until the transferee gives notice of the transfer in the manner hereinafter provided (Section ro-ro7).

(2) Any other bulk transfer subject to this Article except one made by auction sale (Section 10-108) is ineffective against any creditor of the transferor unless at least ten days before the goods are moved or the transferee takes possession of them or the interest of the transferor passes to the transferee, whichever happens first, the transferee gives notice of the transfer in the manner hereafter provided (Section r0-107).

The comment to the Section indicates that the purpose of Subsection ( $I$ ) is to notify other creditors so that they may decide whether to object on the ground that the transfer. may constitute a preference under the Bankruptcy Act. Since there is generally nothing improper about such a transfer, and since attack may be made within four months under the Bankruptcy Act, notice need not be given in advance of the transfer. ${ }^{40}$ The transfer is ineffective, i.e., creates no rights in favor of the transferee, until the notice is given. That sanction seems appropriate.

Subsection (2) is the heart of any bulk sales statute. Notice in advance is con-

\footnotetext{
${ }^{38}$ See, e.g., 3 Muck. CoMp. Laws $\$ 442.1$ (1948) “. . . unless the seller . . . and purchaser . . . shall ... make a full detailed inventory, showing the quantity and, so far as possible with the exercise of reasonable diligence, the cost price to the seller . . . of each article to be included in the sale. . .." The provision is typical.

${ }^{39}$ Walton r. Walter Fisher Co., 146 Miss. 29I, i I I So. 364 (1927).

${ }^{10}$ See Comment 4 to $\$ 10-105$, Spring 1950 Draft.
} 
sidered to be the only effective way of protecting creditors. It is during that period that creditors may take any appropriate action to stop the sale if it is an improper one, or may assert pressure to see to it that their interests are properly protected. In the absence of such a provision the transferor could pocket the proceeds and disappear, the very thing which the statutes are designed to prevent. Of course, notice is of less importance where there is a requirement of application of proceeds, but nevertheless it remains of value. For instance, the consideration may be manifestly unfair, in which case the creditor may seek to have the transaction set aside as a fraudulent conveyance; or there may be omitted creditors who may receive notice only because of the fact that other creditors have been notified, and who may, therefore, file their claims in time to participate in the distribution.

Section ro-ro6 is the most controversial Section of this Article. As yet no agreement has been reached as to whether it should be included at all. ${ }^{41}$ It provides an additional requirement in cases where new consideration becomes available to the transferor as a result of the transfer, in the following language:

In addition to the requirements of the two preceding Sections:

(I) Upon every bulk transfer subject to this Article for which new consideration becomes payable except those made by sale at auction it is the duty of the transferee to assure that such consideration is applied so far as necessary to pay those debts of the transferor which are either shown on the list furnished by the transferor (Section ro-104) or filed in writing in the place stated in the notice (Section I0-I07) within thirty days after the mailing of such notice. This duty of the transferee runs to all the holders of such debts, and may be enforced by any of them for the benefit of all.

(2) If any of said debts are in dispute the necessary sum may be withheld from distribution until the dispute is settled or adjudicated.

(3) If the consideration payable is not enough to pay all of the said debts in full distribution shall be made prorata.

An obligation of this sort is now imposed by the statutes of nine states, those statutes being in what is called the "Pennsylvania form." 42 It is designed to afford an even greater degree of protection to creditors. The principal objection is that it imposes too great a burden on the transferee. In this respect, two things should be

\$2 The Note found in the Spring 1950 Draft, as corrected by Professor Bunn's letter referred to in footnote 5, supra, reads in part:

"This section is in brackets to indicate doubt whether the Act should impose any obligation on bulk buyers to see to the application of the proceeds.

"No such obligation is imposed by the law of New York or of those states which follow New York in this respect. It is imposed by the law of Pennsylvania and the states which follow Pennsylvania. A substantial number of states are in each group.

"The draft of the Act considered at the Washington meeting (May r949) contained a provision corresponding to this, which then received tentative approval. The sense of the St. Louis meeting (September 1949) was however that it be eliminated. The May, x950, meeting voted to retain the section, but in brackets, in order that a later meeting, or individual states, might decide the question finally."

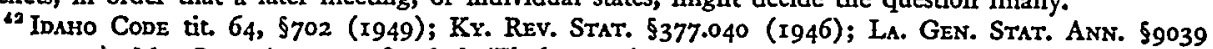
(Dart, I939); MD. Code ANN. art. 83, \$98 (Flack, 1939); 2 MoNT. Rev. Code ANN. \$I8-202 (I947); 3 Nev. Cosm. Luws $\$ 6817$ (Hillyer, 1929); PA. Stat. ANs. tit. 69, \$523 (Purdon Perm. ed); 2 Utah Code ANN. $\$ 33-2-2$ (I943); 7 Wash. Rev. Stat. ANN. $\$ 5833$ (Remington, 1932) as amended by Wash. Laws I939, c. I22 and Wash. Laws I943, c. 98. 
noticed. (I) The only creditors protected are those listed plus those who file a claim within thirty days. This limitation considerably lessens the burden on the transferor. (2) Earlier drafts provided certain ways in which the obligation imposed by the section could be met. ${ }^{43}$ Three suggested methods were (a) an escrow arrangement, (b) payment into court, or (c) acceptance of a bond from transferor with a corporate surety. These methods were not intended to be exclusive. The Comment to the Section found in the. May I949 Draft suggests that ". . . deposit of the consideration in a special account subject to checks countersigned by the transferee or his agent" would be a simpler and yet suitable method. That Section of the Article has been eliminated, apparently on the theory that those methods of meeting the requirement would be available without express mention. It would seem, therefore, that by carefully limiting the duty of the transferee, the draftsman has eliminated the major source of objection. In any event the matter is not settled at the time of this writing.

Section ro-ro7 provides for two forms of notice, one to be used if the transferor's debts are to be paid in full as they fall due, the other where they are not to be so paid. In the former situation

(I) The notice to creditors (Section I0-I05) shall state:

(a) that a bulk transfer is about to be made;

(b) the names and business addresses of the transferor and transferee, and all other business names and addresses used by the transferor within three years last past so far as known to the transferee; and

(c) whether or not all the debts of the transferor are to be paid in full as they fall due as a result of the transaction, and if so, the address to which creditors should send their bills.

If the debts are to be paid in full, it seems clear that a simple form of notice will suffice. The creditors only need to know where to send their bills, and the notice will inform them.

On the other hand, if debts are not paid in full, or where the transferee is doubtful about it, the creditors will want, and are entitled to, considerably more information. They will certainly want information which will enable them to determine whether the transaction is a voidable preference under the Bankruptcy Act, or a conveyance

${ }^{4}$.Section 7-7ro of the May 1949 Draft provided:

"Without prejudice to other means of performance, the obligation of the transferee for new considera. tion (Section. 7-707) and of the auctioneer (Section 7-708) to assure due application of the procceds is performed by:

"(a) deposit of the consideration with a responsible agency under an agrecment by it to apply so much as may be needed to pay the transferor's debts as they may be established by a reasonable method and within a reasonable period fixed by the agreement and of which notice is given, and to pay the balance to the transferor. Thirty days after the notice is a reasonable period for the original filing of claims; or

"(b) payment of the consideration into the registry of an appropriate court for distribution among the creditors of the transferor-according to their several priorities; or

"(c) acceptance of the transferor's bond with corporate surety in an amount at least cqual to the consideration for the transfer and conditioned for prompt payment of the transferor's debts. If such a bond is given any creditor of the transferor may maintain an action on it for the benefit of all such creditors." 
fraudulent in fact because of inadequacy of consideration. Therefore, in that situation the notice must also state:

(a) the location and general description of the property to be transferred and the estimated total of the transferor's debts;

(b) the address where the schedule of property and list of creditors (Section ro-104) may be inspected;

(c) whether the transfer is to secure or pay existing debts and if so the amount of such debts and to whom owing;

(d) whether the transfer is for new consideration and if so the amount of such consideration and the time and place of payment; and

(e) if for new consideration the time and place where creditors of the transferor are to file their claims.

Obviously if Section I0-I06 relating to the application of proceeds drops out of the Article, Subsection (e) of Section I0-I07(2) must also drop out. The Section is largely self-explanatory but the distinction between Subsection (c) and Subsection (d) should be noted. Subsection (c) relates to transfers not for new value. Earlier drafts of the Article contained a separate section stating that in the case of transfers in payment of old debts, the standard notice in advance must be given. ${ }^{44}$ This section has been dropped, presumably because it was superfluous. The rule laid down there is implicit in the remaining sections. The situation where the transfer is to secure old debts has been discussed in connection with Section ro-ro5 and particularly Subsection ( $\mathrm{I}$ ) thereof. In neither of those situations does any new consideration become available.

Subsection (d), on the other hand, can be applicable only when the transfer is for new consideration (and it is so stated in the Subsection), since it provides for a statement as to the amount of that consideration and where it is to be paid.

Section ro-108 relates the special rules applicable when the transfer is to be at auction. Obviously an auction will be utilized only where the transfer is an outright sale for new consideration. It provides:

(x) A bulk transfer is subject to this Article even though it is by sale at auction, but only in the manner and with the results stated in this section.

(2) The transferor shall furnish a list of his creditors and assist in the preparation of a schedule of the property to be sold, both prepared as before stated (Section ro-ro4).

(3) The person or persons other than the transferor who direct, control or are responsible for the auction are collectively called the "auctioneer." The auctioneer shall:

(a) receive and retain the list of creditors and prepare and retain the schedule of property for the period stated in this Article (Section ro-I04);

(b) give notice of the auction personally or by registered mail at least ten days

"Section 7-706 of the May 1949 Draft was as follows:

"In addition to the requirements concerning scheduling of property and listing of creditors . . . a bulk transfer subject to this Part in payment of an existing debt or debts is ineffective against any unpaid creditor of the transferor unless at least ten days before the goods are moved or the transferee takes possession of them or the interest of the transferor passes to the transferee, whichever happens first, the transferee gives notice of the transfer pursuant to the provisions of this Part on notice...." 
before it occurs to all persons shown on the list of creditors and to all other persons who are known to him to hold or assert claims against the transferor; and

(c) assure that the net proceeds of the auction are applied as provided in this Article (Section 10-106).

(4) Failure of the auctioneer to perform any of these duties does not affect the validity of the sale or the title of the purchasers, but it renders the auctioneer liable to the creditors of the transferor as a class for the sums owing to them from the transferor up to but not exceeding the net proceeds of the auction. If the auctioneer consists of several persons, their liability is joint and several.

Again it is clear that if Section ro-106 drops out, Subsection ro-108(3)(c) must also drop out.

This Section, too, is self-explanatory, but it should be emphasized that the risk of liability is on the auctioneer and not on the individual purchasers at the sale. A few of the existing statutes so provide, ${ }^{45}$ but the idea is not so clearly stated as here. The provision is an important one for if auction sales are excluded ". . . the way would be open to a debtor to carry out a bulk transfer of his property without notice to his creditors and without any duty upon anyone to see to the application of the proceeds. ...."46

Section IO-IO9 is another very important and somewhat controversial section. It first describes which creditors are entitled to the benefit of the statute in the following language:

(1) The creditors of the transferor mentioned in this Article are those holding claims based on transactions or events occurring before the bulk transfer.

That definition of creditors is broader than that found in any of the cases decided under the existing statutes. ${ }^{47}$ It apparently includes claims whether they are in tort or contract, are liquidated or unliquidated, are secured or unsecured, are contingent or fixed, are presently due or not. An earlier draft so provided. ${ }^{48}$ Despite the absence of such language in this draft, nothing appears to limit the breadth of the definition in any way. It is recognized by the Reporter for the Article that "This all-inclusive listing may make it hard for the transferee to perform his obligation to assure due application of the proceeds." His answer, however, is that "If the affairs of the transferor are so involved as to make it impractical to handle that obligation otherwise ..." the transferee should pay the proceeds into the registry of the appropriate court for distribution. ${ }^{49}$

Subsection (2) which is to be included only if Section ro-ro6 relating to the application of proceeds is retained provides for something like subrogation:

\footnotetext{
${ }^{45}$ Cal. Civ. Code $\$ 3440$ (Deering, 1949); Kr. Rev. Stat. $\$ 377.050$ (1946); Pa. Stat. Ann. tit. $69, \$ 523$ (Purdon, Perm. ed).

${ }^{40}$ Comment to $\$ 10-108$, Spring, I950 Draft.

${ }^{17} \mathrm{Sec}$ Notes, 84 A. L. R. 1406 (1933) and r02 A.L.R. 565 (1936); See also Note, 71 U. S. L. Rev. 607 (1937); Note, 21 Notre Dame Law. I34 (1945); Comment, ro Tulane L. Rev. 131 (1935).

${ }^{8}$ See $\$ 7-711$ of the May 1949 Draft.

10 The quoted language is from the Comment to $\$ 7-711$ of the May 1949 Draft. It is not found in the Comment to \$ro-rog (the superseding provision) of the Spring r950 Draft.
} 
(2) Against the aggregate obligation imposed by the provisions of this Article concerning the application of the proceeds (Sections 10-106 and subsection $(3)(c)$ of 10-108) the transferee or auctioneer is entitled to credit for sums paid to particular creditors of the transferor, not exceeding the sums believed in good faith at the time of the payment to be properly payable to such creditors.

Under this wording, the idea that the responsibility for the completeness of the list of creditors rests with the transferor is reinforced.

Section I0-IIo provides that whether one who purchases from a non-complying transferee takes subject to defects in such transferee's title, depends entirely on whether he had knowledge or notice of the defect. The rule seems clearly correct and represents the state of the existing law on the point. ${ }^{50}$

Section IO-III is the limitations section. It provides that:

No action under this Article shall be brought more than six months after the date on which the transferee took possession of the goods unless the transfer has been concealed. If the transfer has been concealed actions may be brought within six months after its discovery.

The Section is self-explanatory.

II

\section{Some Effects on Commercial Practices}

One question asked on the questionnaire referred to above related to the extent that escrow agreements have been used. Only the Missouri statute specifically provides that the purchase price may be put in escrow, ${ }^{61}$ but it does not seem that any express statutory authorization is necessary. Thirteen persons answered the questionnaire. Nine of them indicated that escrow arrangements are seldom used in their territory, while four indicated that they are frequently used. Particularly if Section 10-106 relating to application of proceeds is included in the final draft of the Article, the escrow arrangement is a very sensible way of avoiding the red tape attendant on that requirement, and it seems likely that it will be a much more widely used device if the Code is adopted in that form.

Another question was whether bonds are ever required. The answers make it clear that they are practically never used. Only the Kansas ${ }^{52}$ and North Carolina ${ }^{53}$ statutes expressly authorize the transferee to receive a bond from the seller in lieu of sending out notices to creditors. It will be recalled that one of the earlier drafts of this Article provided that “. . . acceptance of the transferor's bond with corporate surety in an amount at least equal to the proceeds and conditioned for prompt payment of the transferor's debts . . ."54 would be an acceptable way of meeting and would considerably lessen the burden of performing the obligation to assure due application of the proceeds. The old Section also provided that "If such a bond is

\footnotetext{
${ }^{80}$ Credit Manual of Commercial Laws, 194r, p. 344 .

cI Mo. Rev. Stat. \$35I7 (r939).

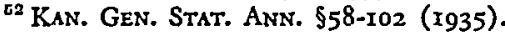

632 N. C. Gen. Strat. $\$ 39-23$ (1943) as amended by N. C. Laws 1945, c. 635 .

st $\$ 7-7$ Io(c) of the May 1949 Draft.
} 
given any creditor of the transferor may maintain an action on it for the benefit of all creditors. ...."55

It is uncertain whether that alternative to compliance would be available without express mention. Certainly if notices are given so that the opportunity pf the creditors to learn of the transaction is not lessened, creditors would be prejudiced in no way by the adoption of that method of complying with the application-of-proceeds requirement. Since that is true, I believe that courts would look favorably on such a procedure and that it could be used safely by the transferee. I further believe that it will come into more common usage if the application-of-proceeds requirement remains in the statute.

Another question related to whether the existing statutes were often ignored because the seller was both honest and solvent. A variety of answers was received. Eight of the persons contacted indicated that the statutes are rarely ignored for this reason, suggesting that the single most important reason for non-compliance is ignorance of the existence of a bulk sales statute. The other five persons questioned indicated, however, that in their areas the statute is often ignored for this reason. In at least two answers, however, the writers frankly stated that their answers were based on opinion and not on knowledge. That is, of course, perfectly understandable, since that sort of transaction is not likely to come to the attention of Credit Men's Associations. One other answer indicated, however, that in most instances the confidence of the transferee in the transferor turned out to be completely unjustified. Obviously that danger cannot be eliminated except by compliance. The important thing to consider is just how serious a danger it is. Is the risk sufficiently small so that the transferee can afford to take that risk in order to avoid the red tape involved in complying with the statute?

Another answerer astutely insisted on distinguishing between situations where the seller was solvent beyond question, and those where he was considered to be honest beyond question. In the first situation, he indicated that compliance was completely unnecessary, but in the second situation his answer was in the negative.

I do not believe that the enactment of this Article will have any great effect on the number of cases in which the act will be completely ignored. That seems to be dependent on external factors such as the solvency and reputation of the individual transferor involved rather than on the provisions of the Article. The Reporter points out, however, that in so far as the application of proceeds requirement is concerned, it can be ignored when the transferee is confident that the transferor can and will pay his debts in ordinary course. ${ }^{56}$ Obviously the choice of ignoring even that requirement would depend on the same external factors.

Still another question related to the existence of fraud in fact in cases where the statutory requirements were not met. Eleven answers indicated that there were few or no cases where any actual fraud existed. One answer indicated quite the reverse, without qualification, while still another indicated that among small storekeepers there was a substantial number of instances where fraud in fact existed.

st thid.

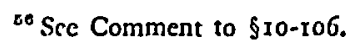




\section{One of the stated purposes of this Article is}

... to assist the policing of the bankruptcy policy against preferences by calling to the attention of all creditors efforts by particular creditors to secure assignments of major parts of the common debtor's business property. . . . It is carried forward here by applying the notice requirement not only to outright transfers for new value, but to bulk transfers in payment of or to secure old debts. . . .57

If it is true, as the answers indicate, that there are practically no cases of fraud in fact anyway, this purpose may well be the most important contribution of the Article, and it is a worthwhile contribution.

It should be noted, however, that the question was somewhat ambiguous. What I intended to ask about was the number of cases where there was any "fraud" on the part of the transferor, regardless of whether the transferee joined in that fraud. If the answers are in response to the question so understood, then the above conclusion as to the major value of the Article seems sound. However, it is not unlikely that those queried understood by "fraud in fact" the typical fraudulent conveyance situation, i.e., the situation where the transferee is a party to the transferor's fraudulent intent. If that be true, there may well be many cases where the transferor alone had a fraudulent intent, and the other major policy of the act, i.e., to prevent the transferor from pocketing the proceeds and disappearing, ${ }^{58}$ remains dominant. I believe that under the latter assumption, the new article will make a major contribution if the application of proceeds requirement is retained. Such a requirement will insure against loss by creditors much more effectively than could any statute without such a provision.

Another question related to the reason for the decrease in bulk sales litigation during the past decade. The majority of those queried simply said that more and more people have learned of the existence of the act, and that, of course, is an important factor. One answer suggested that the law was too weak, others that the cost of availing one's self of remedies under the act outweighed the relief which could be obtained, especially in small transactions. On the other hand, one answer indicated that a properly supervised bulk sale has been found to be a quick and effective method of receiving a fair return in an insolvency case, and so has been generally used. 59

To the extent that litigation has decreased due to the fact that the bulk sale in compliance with a bulk sales statute has been found to be a commercially expedient method of handling a difficult situation, I am certain that adoption of this Article will continue the downward trend in bulk sales litigation. In my opinion it is a superior job of draftsmanship, one which reflects careful thought and meticulous weighing of choices, necessitated by the fact that the interests of creditors always conflict with the interests of purchasers. Because of that fact, I think the end product will prove more workable than any of the existing statutes, and that, therefore, cases of non-compliance will continue to decrease in number.

\footnotetext{
${ }^{67}$ See Comment to §ro-ror.

${ }^{5}$ See also Harris, The Bulk Sales As a Vehicle for Effecting Out-pf-Court Settlement With Creditors, 55 CoM. L. J. 3I7 (r950).
} 